
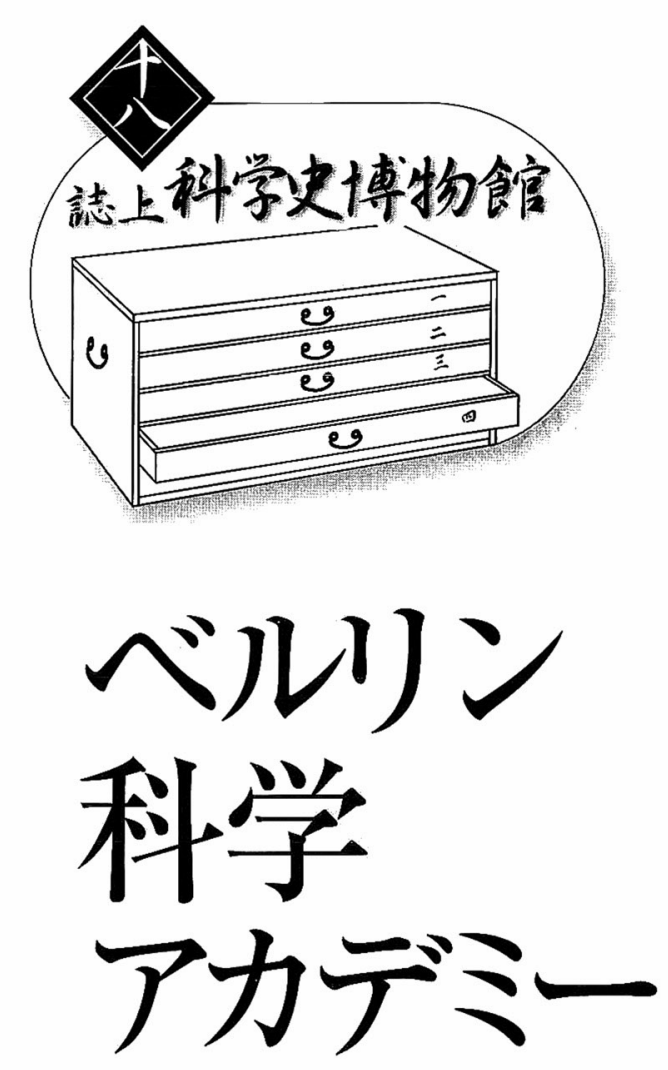

\section{ードイツの科学アカテミー、その(2) 一}

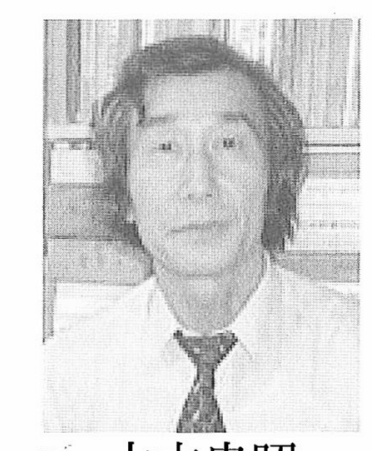

木本忠昭

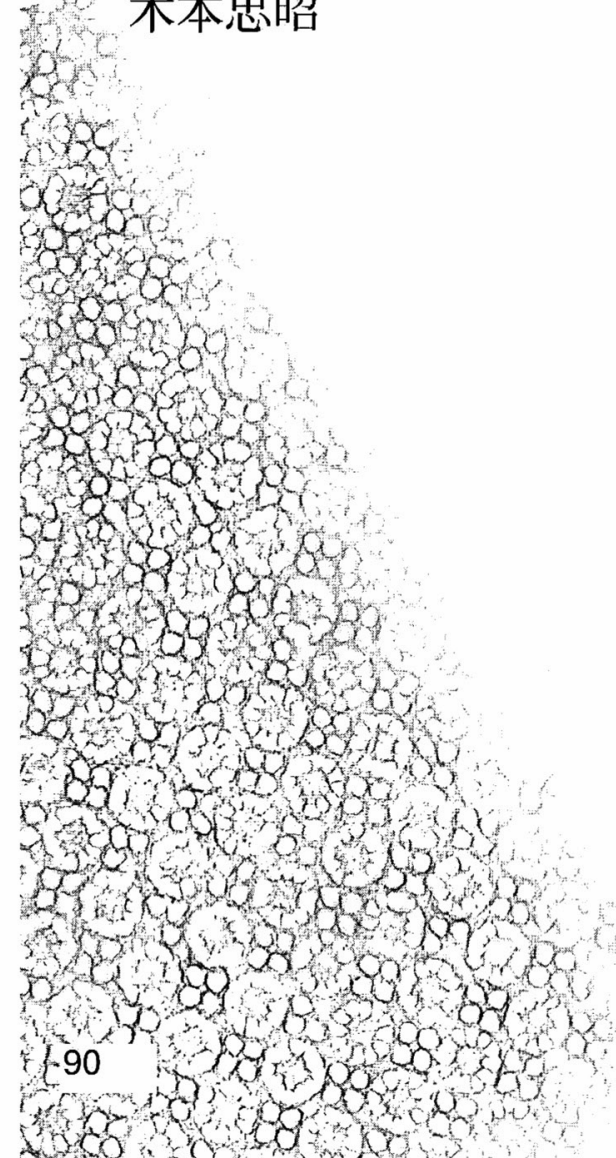

英仏科学アカデミーと ベルリン科学アカデミーの違い

前回は、自由都市シュヴァインフルトで発足された ドイツ現存最古の医学自然科学アカデミー・レオポル デイーナを取り上げた。このレオポルデイーナの創設 と展開を見ると、科学的な活動を支えるのは、穴れな りの政治的自由と社会的経済的基盤が必要であったこ とを示している。今回取り上げるベルリン科学アカデ ミーも、まさに、中世的政治体制の転換期を表徵する 啓蒙君主そして、転換期の学者が関わって成立したも のである。

イギリスのRoyal Society of Londonやフランスの Académie des Scienceは、社会転換期において大学 の学者とは違う新しいタイプの科学者の台頭によって 創設されたものであった。ドイッのベルリンで創設さ れた科学アカデミーも、そのような特徴があった。し かし、英仏のアカデミー設立とは大きな違いがあっ た。英仏のアカデミーは、経済社会的変化を背景に、 新しいタイプの自然研究者たちが、実験的な研究活動 を行うために自ら「非公式」の「会」を設立し、それ が政治的に啓蒙主義的な君主の庇護をうける形で展開 していっだ。ドイッでは、英仏と比較すれば社会的 政治的状況がちがいそうした新しいタイプの学者が多 く排出して自由な活動を展開するまでには至っていな かった。一人の学者Gottfried Wilhelm von Leibniz の先見的提案一といってもイタリアや英仏の後塵を 拝するものであるが一が、最初から、新「科学的」 知識が新たな経済展開との結合の可能性を見いだした 専制君主の直接的関与のもとでアカデミーの創設とな ったのである。

こうした設立経過、とくに王権の庇護をうけるとい うことから、英独仏学れぞれのアカデミーは、機械や 化学、あるいは産業に関係する実際的知識に関して強 い関心をもつ新しい知識人の会となったものの、しか 
し、王権との摩擦をもたらすであろう問題の 議論・研究は避けた。別の形での歴史的制約 があったのである。たとえば、1663年、フッ クが草したRoyal Socity of Londonの規約前 文の案でさえも、次のようになっていた。

王立協会の事業は、自然物の知識および 一切の有用な工芸・製造業・機械の実務· 原動機・実験による発明を改良することで ある。(神学・形而上学・道徳 · 政治 - 文 法・修辞・論理学には介入しない。 $)^{2}$

\section{ライプニッツ(G.W.von Leibniz)}

ベルリン科学アカデミーの創設者となった ライプニッツGottfried Wilhelm von Leibniz （1646-1716）は、周知のように、政治家的な 仕事だけでなく、法学、歴史学、哲学、神学、 経済学、さらに微積分記号なざ数学や論理計 算、記号表記、2進法、また計算器の考案など 17世紀に抢ける諸分野の研究に業䋶を残した 「知的巨人」といわれる。個別科学だけでなく モナド (単子) 論によって諸学の体系付けをも 展望している。はじめ、当時としてはもっと も保守的な大学といわれるライプチッヒで法 学を、ついでJacob Thomasius ${ }^{3}$ に哲学を学 ぶ。イエーナ大学にうつり、数学、占星術・ 天文学、そして法律や哲学でも名を馳せたワ イゲルWeigelに数学を学んだ。ワイゲルはス コラ哲学に反対し、1673年には数学者の会 Societas Pythagorea (ピタゴラス哲学の会) を結成していた。被の教室は満杯で、ライプ ニッッも少なから奴影響を受けたといわ机て いる。ライプニッツは、ライプチッヒに帰っ て、法学に専念したが、法学博士の学位は取 得できなかった。先の理由は、彼の思想が当 時のキリスト教的な「大学知」(univerșity)

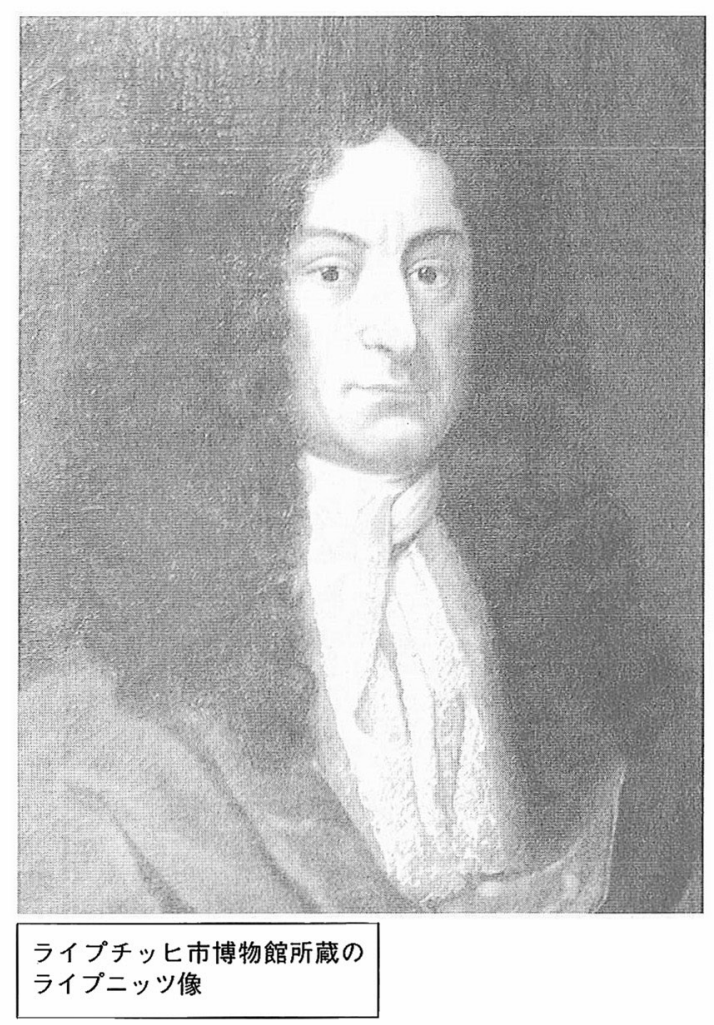

に対立するものであったとの説がある゙。それ で、ライプニッツは、当時もっとも進歩的と

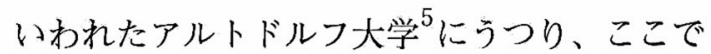
学位を取得する。ここは、後、1672年に、J.C. シュトウルムが、フィレンチェの科学アカデ ミー「デル・チメント」をモデルにして、「知 欲もしくは実験の会」(Collegium curiosum sive experimenta）を設置したところである。 ライプニッッは、ここで鍊金術師の団体と接 触し、そのやり方には批判をもつが実験科学 への関心を強めていくことになった。

その後アルトドルフ大学の教授職就任を辞 退、マインツ選定候の外交官となり、以後パ リをはじめヨーロッパ各地を遍歴することと なる。パリでは、ホイヘンス、ロンドンでは、 王立学会 (Royal Society of London) の会員 になり、ニュートンやバローの研究を知るな ど当時の著名な科学研究者スピノザらの哲学 者と交流する。書簡でも多くの知識人と意見 


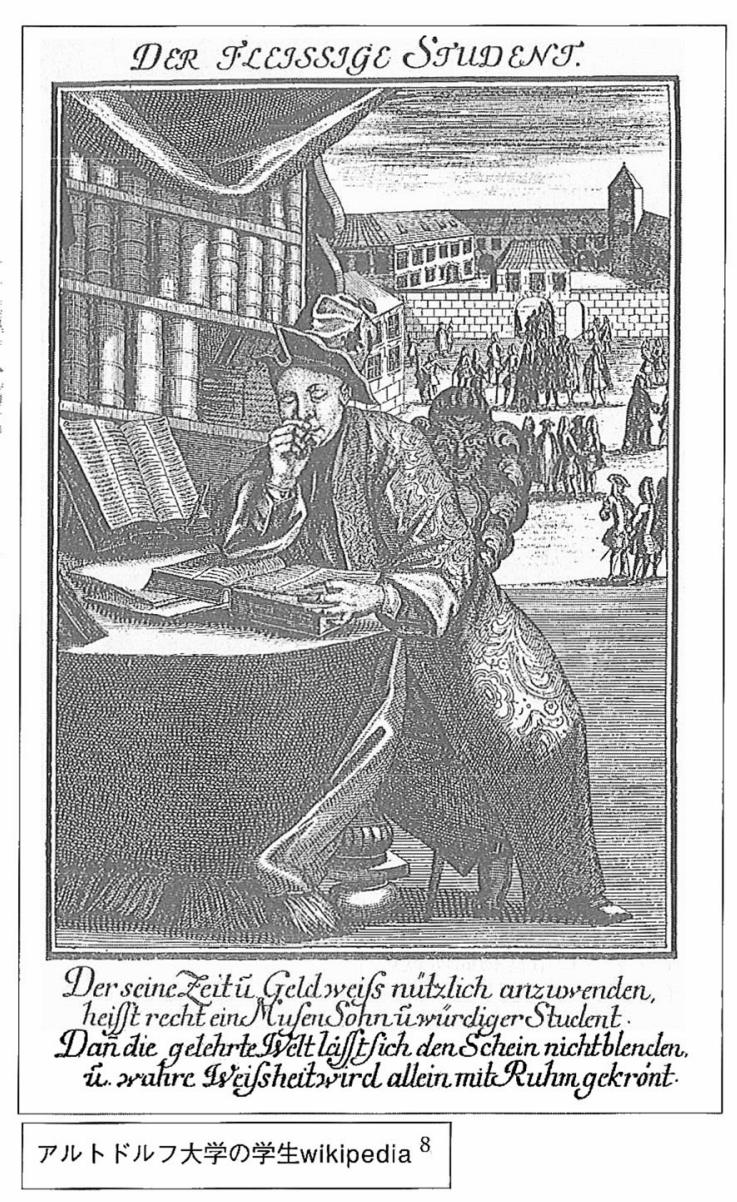

交換を行っている。1663年から1716年（没年） まで20,000通の手紙がライプニッツに宛てら れたと目されている。その中、約15000通が、 ライプニッッ・アーカイブズに記録されてい る ${ }^{6}$ 。これらの手紙差出人は 16 力国 1100 人に及 んでいる。フリードリッヒ大王は彼のことを 「彼の中に全アカデミーがある」と表したとい われる ${ }^{7}$ が、まさに彼の中に当時の一つの科学 界、知識社会ができあがっていたのである。

\section{ライプニッツのアカデミーへの期待}

諸国遍歴と新しいタイプの知識人との交流 から、ライプニッツには新たな知的体系構築 の展望が形成される。これは、ラテン語に基 礎を置く古い知的体系と教育に反対し、ベー コンやデカルトが、ラテン語でなく英語やフ ランス語を使ったように、自国語つまりドイ
ツ語を使うことによって古いスコラ主義を克 服しようとすることにもつながった。彼は、 宇宙に関する「古い知的体系」を修道院的と呼 び、プロテスタントとカソリックの和解を考 える一方で、啓蒙への知的前進を願い、その ために新たな「学識人の組織」を求めた。もち ろん、後者は英仏の、Royal Societyと Akademie des Sciences が念頭にあった。ラ イプニッッの学識人組織に対する考方方は、 当時のドイツの社会的経済的状沉を強く意識 したものになっている。『ドイツに扔ける科学 工芸受容のための社会的組織設置の基本的構 想』には、次のように述べられている。

「機械での大発明がなされ、生理学や化学 での大発見があり、これらは新しい光を投 げかけている。しかし、ドイッの実際生活 は依然として元のままで、発明は人間生活 の幸福や豊かさに有用化されていない。そ のためには、ドイッ人は、隣国のようにア カデミーを設置する必要がある。アカデミ 一をつくれば、経験を伝えあい協同精神を 目覚めさせ、（伝達手段をつくれるので）発 明家たちの経験や発明を有用化させること が出来る」 9

そして、アカデミーでは、諸分野において の大規模な研究が遂行され、機械器具の導入 で製造業の改良、労働や取引が改善され、ま た学校教育もアカデミーが指導し、孤児や捨 て子は技術教育が施されるべきだとする。ま た、新しい知識を伝達しあうために雑誌を創 刊するものとされた。

さらに、他国にくらべ「ドイツ人は、発明 を真っ先にするが、それらを利用するのは最 後だ」と嘆いている。ドイッ人は鉱山や化学、 機械で大きな仕事をしてきた。自動機械もド 
イツ人が発明した。レギオモンタヌスやコペ ルニクス、チコ、ケプラーはドイッ人だ。治 療医術、鍊金術や薬術はドイッで栄えたもの である、輸血は最初にドイツ人が試した。し かし、これらの発明は外国に持っていかれ、 後に、形を変えて、新奇なものとして外国か ら輸入される始末だ。こうした事が起きる理 由は、ドイッには、英仏のようなアカデミー 組織がないからである、というわけである。

そのためには、当時のFruchtbrigende Gesellschaftと Collegium Naturae Curiosorumを統一し、帝国国家的な組織にな る必要があるとし、会員としてふさわしい人 物を 48 人挙げてもいる

\section{アカデミーの創設}

1700年、ブランデンブルク選定候Friedrich III世にベルリンに招かれたライプニッツは、 持論を展開した。選定候は、ライプニッッの 学識に感銘し、またライプニッツの説くアカ デミーのドイツ的意義を認めてドイツの科学 アカデミーを設立することを決めた。モデル は当然英仏の科学アカデミーであった。選定 候は、翌年プロイセン王国を成立させ、自ら Friedrich I 世王を名乗るが、こうしてドイッ の科学アカデミーはプロイセン国家の成立と 軌を一にすることとなった。会長は当然ライ プニッツが任命された。ただし、アカデミー の名称は、アカデミーではなく、「ブランデン ブルク科学会」（Kurfuerstrich Brandenburgische Sozietaet der Wissenschaft) ${ }^{11}$ を名乗ることとなった。名称 が、Sozietaet となったのは、ライプニッッ の強い意向によるものであった。当時、アカ デミーにはすでに種々のものがあり、科学者
の研究（交流）を目的にする ものばかりではなく教育機能 をもつものもあったところか ら、ライプニッツは、前者を

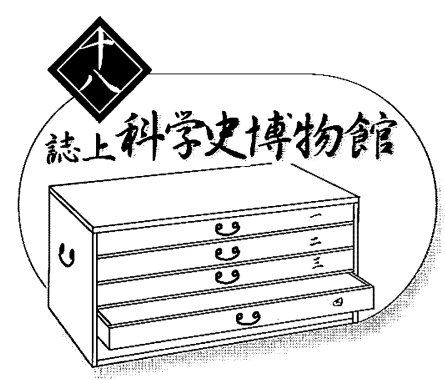
目的とすることを明確にする ため、アカデミーとは別の名 称を選択したのである。1710年、最初の定款 が決めら机、会員選出の方法や数、会の構成 等が定められた。会員選出は会員による新秘 密補充選挙によって行われ、以後 300 年間に、 国内外の全科学分野にわたって 3500 人以上が 会員として選ばれている。1711年1月19日発会 式が行われたが、1718年には17世紀に設置さ れた植物園を併合、23年には医学自然科学教 育機関としてCollegium Medico-chirurgicum を設立するなど組織的整備が進んだ。 40 年フ リードリッヒI世がプロイセン王になると、 王はすぐに会の改革に着手、44年には前年設 立した文学会 (Sociétié Littéraire de Berlin) を統合し、名称を「王立科学アカデミー」と 改称した。

プロイセンは、神聖ローマ帝国の中にあっ て国家体制を法的液㓮的整備をすすめるとと もに隣国との戦争・政争を展開、徐々に中欧 での強権体制を形成していった。18世紀後半 から19世紀前半には、「シュトルム・ウント ・ ドランク(疾風怒濤)」の時代を迎え、ドイッ 古典文学の花が開花、カントや、クリスティ

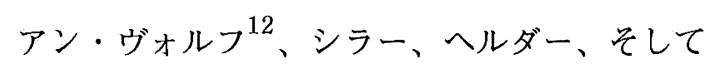
ゲーテ、ヘーゲルらの大活躍の時代を迎える。 社会的には1806年のナポレオンの侵攻、ベル リン入城によって、プロシアの領土は半減、 屈辱を味わうこととなった。こうした混乱の 中で、1807 10年のシュタイン・ハルデンベ ルク改革、徴兵義務を求めるホルストの軍政 
改革などで、国家体制の再構築が行われた。 こうしてドイッ・プロイセンの近代化は、ナ ポレオン軍の介入のもとで改革派と王権の葛 藤の中で複雑に展開していった。しかし、 1812年にはナポレオン軍に対するライプチッ ヒの国民的抵抗の勝利によって強権的なプロ け侪セン国家の軌道が強化されていった。

こうした国内の大変動は、プロイセン科学 アカデミーにも大きな影響を与えたのはいう までもない。シュタイン・ハルデンベルク改 革の流れは、プロイセンの教育と学術体制を 大きく変え、アカデミーの会員ヴィルヘル ム・フンボルトや弟のアレクサンダー・フン ボルトの主導で1810年にはドイッではじめて の近代的大学、ベルリン大学 (総長フィヒテ) が創設された。そして、アカデミ一の研究施 設は大学に移された。それまでの研究施設を 活動母体にしていた研究者が大学に移り、ア カデミーの機能も変わっていった。1815年以 後には、大学に詨してアカデミーの側の機能 は、研究論文の出版や、諸科学の個別問題の 編集活動の委員会をつくるということになっ た。アカデミーは会員の研究成果の発表や討 論会、全体会議などを開くことによって科学 研究・進歩の上で重要な役割を果たすことと なった。しかし、アカデミーと大学との連携
の形は、さらに変化しはじめ、20世紀にはい るとアカデミーは自前の研究を維持し、研究 者を集めようとしはじめる。

\section{アカデミーと懸賞問題}

プロイセン国家の拡大と近代社会の形成が 表裏の如く重社合わせながら展開する社会に あっては、アカデミーは現実から遊離した単 なる抽象的な知的活動のみにとどまるわけに はいかなかった。

この頃のアカデミーの特別な活動として㲘 賞問題がある。䯚賞問題はもちろん知的関心 上からも大きな問題ではあったが、同時に経 済・農業振嬹上の課題にも関連があった。こ の点は、前回に述べたLeopoldinaの場合も同 じであった。

プロイセン科学アカデミーの懸賞問題に関 連して、1746年から1806年の間でも2000回も 会議が開かれている13。

アカデミーの䯚賞問題が、現実の経済的、 農業的あるいは人間の社会的諸活動との関連 を持っていたことは、アカデミーの創設その ものが、中世の大学の「閉じた世界」での宗教 的活動と結びついた学問から、新しい経済的 社会的変化と軌を一にした関係にあったこと でもあり、とくに不思議なことではない。 

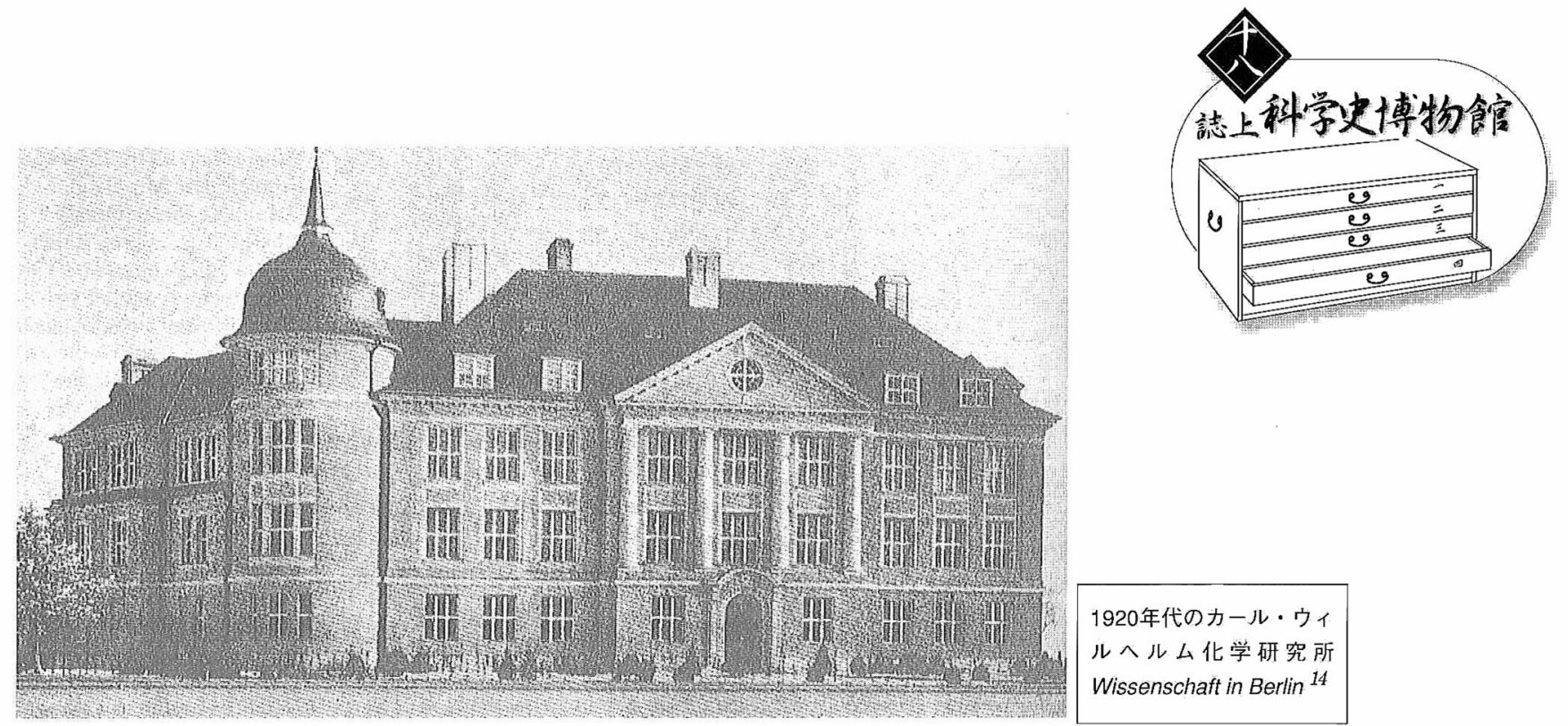

\section{プロイセン科学アカデミーの栄光}

19世紀末から20世紀にかけて、ラジウムや、 X線、陰極線の発見など物理学や化学の領域で の新発見に対応する理論的な研究の遅れによっ ていわゆる「物理学の危機」の時代がくる。

不可知論や神秘主義も流行ったが、やがて世 紀が変わると自然科学研究の新しい流れが出来 てくる。ノーベル賞も開設された。

ノーベル賞は、プロイセン科学アカデミーか らは、第1回 (1901) 受賞者のレントゲン (物理) やファント・ホッフ(化学)、ベーリング (医学) をはじめ、每年のように受賞者を出した。こう してプロイセン科学アカデミーは、エネルギー 量子仮説の提唱者マックス・プランク、コレラ 菌発見者のコッホ、あるいは $\mathrm{E}$ ，フィッシャー、 F.レーナルト、A.バイヤー、F.ブラウン、W．ウ イーン、ラウエ、アインシュタイン等々の著名 な科学者の組織として、20世紀に扔ける自然科 学研究の急速な発展にあわせたかのようなドイ ツ科学の興隆を象徴することになった。

\section{アインシュタインの除名}

以後のプロイセン科学アカデミーの変遷を端
的に示した人物はアインシュタインである。

スイスのチューリヒ工科大学の理論物理学教

授であった1921年にノーベル賞を受賞するア

インシュタインも1913年にプロイセン科学ア

\section{プロイセン科学アカデミー年表}

\begin{tabular}{|l|}
\hline 1710 \\
1733 \\
1740 \\
1744 \\
1788 \\
1806 \\
1809 \\
1810 \\
1812 \\
1838 \\
1893 \\
1899 \\
1900 \\
1933 \\
1946 \\
\\
\\
\\
1968 \\
1972 \\
1973 \\
1992 \\
1993 \\
\hline
\end{tabular}

\section{アカデミーの定款公表}

Daniel Ernst Jabronski会長

フリードリッヒル 会の改組

会Sozietaetを王立科学アカデミーと改名

初のアカデミーのドイツ語での出版

A.フンボルト、根本的改革を示唆

W.フンボルト、教育やアカデミーの改革

W.フンボルト、ベルリン大学創設

アカデミー、図書館、アルヒーフ以外の全研究施設を大学移管

アカデミーは一般的な科学を振興と性格規定

ゲッチンゲン、ライプチッヒ、ミュンヘン、ウイーンの連合体

を形成、プロイセンも1906から加盟

アカデミーの国際組織が形成され1914まで活動。

これには24アカデミーが参加

ノーベル物理学賞、化学賞、医学賞、文学賞開始

ナチ政権樹立に伴い、国家がアカデミーに影響。

やがては、ユダヤ人をアカデミーから排除

ライプニッツ生誕300年記念、ソビエト占領区で活動再開。

チ同調者の追放。これまでのプロイセン科学アカデミーをべル リンのドイツ科学アカデミーと改名、同時に最前線の科学研究 機関として機能を拡大させる方向性

社会主義の研究体と規定

DDR科学アカデミーと改名

1893来の西ドイツのアカデミー連合体はBRD科学アカデー会

議と称す

BRD科学評議会決定でDDRアカデミーの研究所解体

ベルリンーブランデンブルク科学アカデミーに改組

他方、Leibniz-Sizietaet創設 

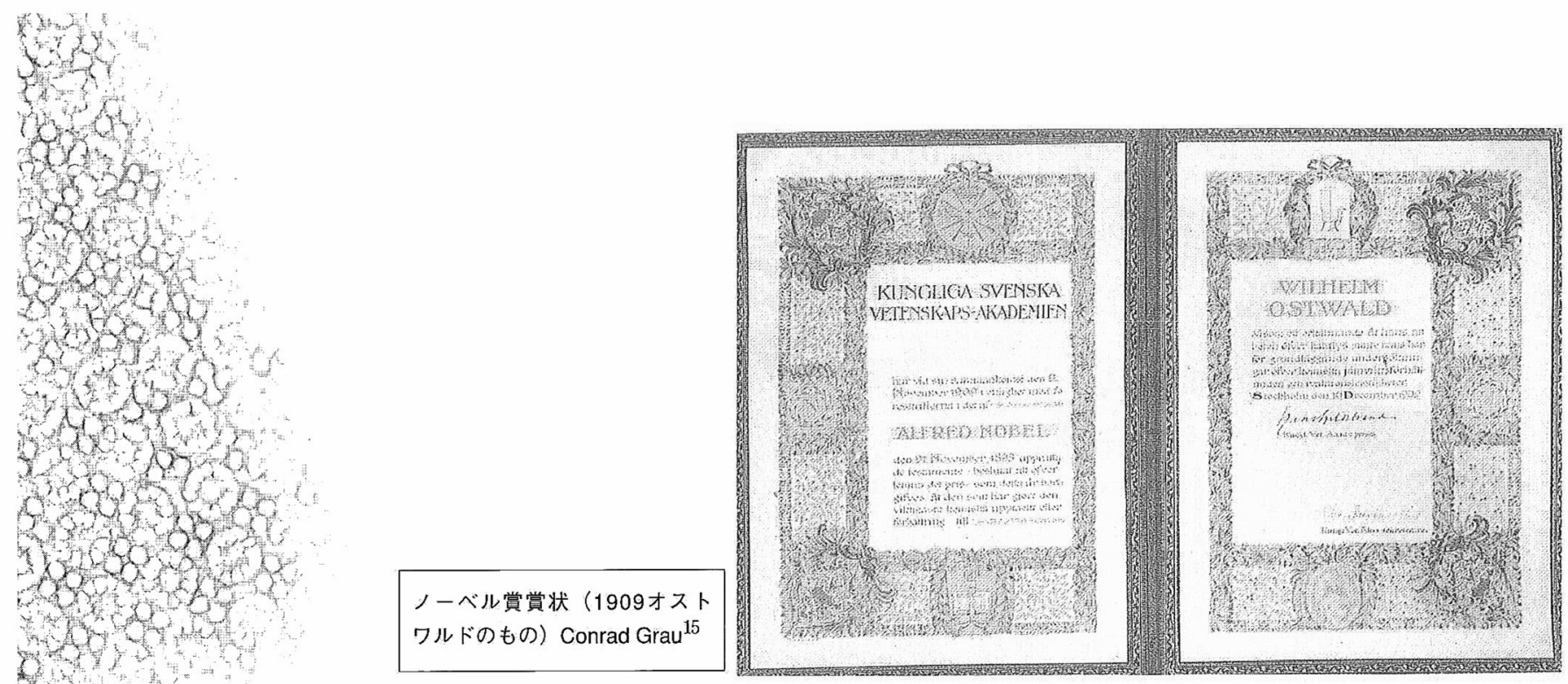

カデミーの会員に選出され、ベルリンに移住 し、カイザー・ウイルヘルム研究所の物理学 部長、ベルリン大学の教授になった。

しかし、1933年、国家社会主義ドイツ労働 者党 (ナチス)が、ドイッ国家の政権について から、人種主義的排外主義政策が強まり、や がてユダヤ人排除の「アーリア (人)科学」なる ものも主張されはじめた。こうした国家によ る科学介入に対して、アインシュタインは、 言論の自由がなく自分がドイツにとどまれる 条件が満たされないとして、プロイセン科学 アカデミーから脱退声明を出し、米国に亡命 することになった。逆にアカデミーは、アイ ンシュタインの除名を決定、極端な国家政策 に従属させた場合の污点を示す歴史を刻むこ とになった。アインシュタインだけでなく、 ドイツ科学の栄光を築いた多くのユダヤ人科 学者もドイツを離れ、その結果、ナチス政権 の下でのドイツ科学発展の道は極端に狭まる こととなった。

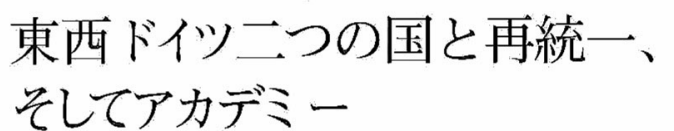

1945年ドイツのナチス政権の敗北とともに、 プロイセン科学アカデミーも新たな歴史が始ま

った。終戦時、アカデミー所在地はソビエト占 領区に属し、以後ソビエト占領政策扣よび東西 ドイッ国家の成立後は、東独（ドイッ民主共和 国)の中で再建と科学活動が展開された。1946 年、ライプニッツ生誕 300 年記念祭が開かれた が、ナチ同調者の追放が行わ机、以後、アカデ ミーの組織構造は根本的に再編されていった。 機能的に見れば、アカデミーは自らを研究組織 と規定し、諸研究所（Institut）を束ねる役割を 持つようになった。元してこれらの研究所は、 国家政策的課題とむすびつけられていった。会 員の選出は、従来通り、科学者の基淮にもとづ く会員による選挙で行われたが、徐々に政権政 党の社会主義統一党の影響力が前面に出るよう になった。まず名称が、これまでのプロイセン 科学アカデミーをべルリンのドイツ科学アカデ ミーと改名された。1968年には社会主義の研究 体と規定され、1972年には東独の西独との分離 政策に伴ってDDR (ドイツ民主共和国) 科学ア カデミーと改名された。

他方、翌1973年には、西ドイツ側でも、1893 年来の西ドイツのアカデミー連合体がBRD（ド イツ連邦共和国) 科学アカデミー会議 (Konferenz der Akademie der Wissenschaften in der Bundesrepublik Deutschland ).と称 

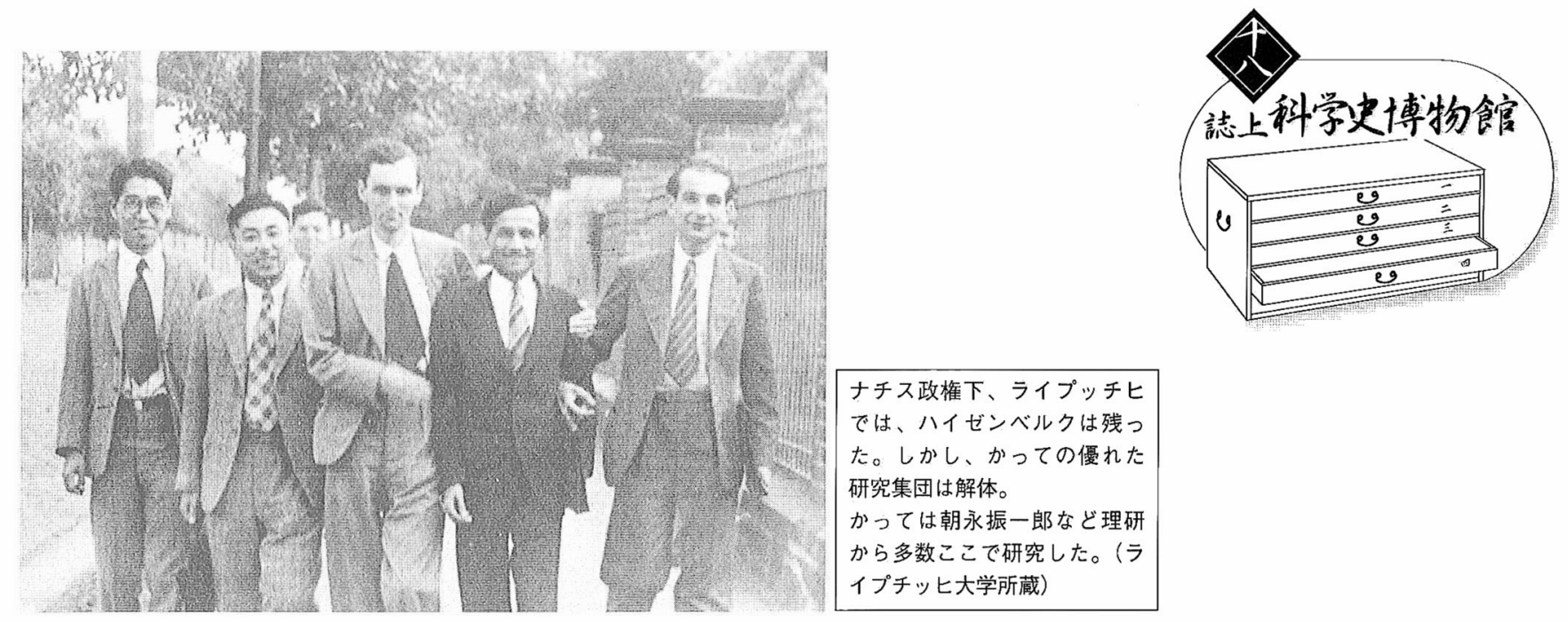

する研究者共同体に再編された。

1990年、ドイツは再統一された。再統一の流 れは、東西研究者にも拈よび、両者の間で協同 的な研究運営や活動協定がいったんは締結され た。しかし、この国をあげての大変動で、91年 にはドイツ連邦共和国科学評議会決定でDDR アカデミーの研究所は解体され、翌 92 年には、 名称もべルリンーブランデンブルク科学アカデ ミーとなった。大学を含め、旧ドイツ民主共和 国の科学者は、「人民裁判」とはいかないまで も、学問的業績以外の基準、たとえば社会主義 統一党への関与が一つの尺度としてもちこま れ、解雇が進められた。こうしてできた科学 者・研究者の「空きポス卜」には、東から西へ の庶民の流れとは逆に、西側からの研究者が東 に「流れ込んだ」。科学界においても、ドイッ の再統一は大きな動乱の時であった。

他方、この年、旧DDRの流れを組む研究者 は、300年前からの伝統的なライプニッツの伝 統を受け継ぎ研究活動を継続するために、90 年の東西研究者の協定にもとづく活動として Leibniz-Sizietaetを創設し、Leibniz Intern を発行、現在に至っている。
注

1 もちろん両者は両国の政治的状況が違うことによって政治権力との 結合形態は異なり、「庇護」の実態も異なった。イギリスでは王室の 後援は金銭的には期待できず、会員は科学研究費は自前で、会の会 費も週1シリングを支払った。会の書記と管理人も、王立学会が財 産をもつまで報酬を求めないこととされた。

2 バナール「歴史における科学』みすず書房 1966年269頁参照。

3 宗教改革者Christian Thomasiusの父。

4 理由は、彼が当時20歳で若すぎるとされたという説もある。

5 1575年、ニュルンベルク市議会の承認のもとにある種のアカデミ 一（学教団体）がつくられ、これが1622年大学に昇格するも、 1809年バイエルン候マクシミリアン1世によって解体。

6 ライプニッツの書簡類の記録は2007年ユネスコの世界遺産プログ ラムに決定された。なお、ライプニッッの業績を記念し、没地の ハノーバでは、2006年大学名をG.W.Leibniz Universitaet Hannover に名称変更した。

7 Martha Ornstein, The Role of Scientific Societies in the Seventeenth Century Chicago 1928 pp186-

8 http://de.wikipedia.org/wiki/Bild:Der_Fleissige_Student.jpg

9 Martha Ornstein, a.a.O p188

10 Martha Ornstein, a.a.O. pp185-186

11 名称は以後何度か変更されるが、呼称も様々に行われた。

12 クリスティアン・ヴォルフ Christian Wolff (1679-1754) ラ イプニッッの推薦で1707年にハレ大学の数学・自然学教授.ドイ ツ語で著作し講義をした。ロンドンやパリ、ストックホルムの各科 学アカデミー会員。ロシアのピョートル1世からは新設のペテルス ブルク・アカデミーの副会長に指名される。フリードリヒ2世（プ ロイセン王) 即位後の1740年、ハレ大学に復帰、1745年に学長。

13 Hans-Heinrich Mueller, Akademie und Wirtschaft im 18. Jahrhundert, 1975s11

14 Wissenschaft inn Berlin 1987 \$356

15 Conrad Grau, Beruehmte Wissenschaftsakademien, 1988 s217

木本忠昭（きもと ただあき 1943年生）

日本学術会議連携会員、東京工業大学大学院社会理工科学研 究科教授

専門：技術史 